\title{
Specificity of DNA import into isolated mitochondria from plants and mammals
}

\author{
M. V. Koulintchenko ${ }^{1,2}$, N. Ibrahim² ${ }^{2}$ E. S. Klimenko ${ }^{1}$, Yu. M. Konstantinov ${ }^{1}$, \\ F. Weber-Lotfi' ${ }^{2}$ A. Dietrich ${ }^{2}$
}

\begin{abstract}
${ }^{1}$ Siberian Institute of Plant Physiology and Biochemistry, Siberian Branch of the Russian Academy of Sciences, 132, Lermontova Str., Irkutsk, Russian Federation, 664033

${ }^{2}$ CNRS Institute of Plant Molecular Biology, University of Strasbourg,

12 ,General Zimmer Str., Strasbourg, France, 67084

mk100171@yahoo.com
\end{abstract}

\begin{abstract}
Aim. Investigation of different features of DNA import into plant and human mitochondria, for a better understanding of mitochondrial genetics and generation of biotechnological tools. Methods. DNA up-take experiments with isolated plant mitochondria, using as substrates various sequences associated or not with the specific terminal inverted repeats (TIRs) present at each end of the plant mitochondrial linear plasmids. Results. It was established that the DNA import efficiency has a non-linear dependence on DNA size. It was shown that import into plant mitochondria of DNA molecules of «medium» sizes, i. e. between 4 and $7 \mathrm{~kb}$, barely has any sequence specificity: neither TIRs from the $11.6 \mathrm{~kb}$ Brassica plasmid, nor TIRs from the Zea mays S-plasmids influenced DNA import into Solanum tuberosum mitochondria. Conclusions. The data obtained support the hypothesis about species-specific import mechanism operating under the mitochondrial linear plasmids transfer into plant mitochondria.
\end{abstract}

Keywords: mitochondrial DNA import, plant mitochondrial linear plasmids, mitochondrial genome.

Introduction. It is well known that horizontal gene transfer (HGT) is one of the substantial factors, mainly in the evolution of bacteria. Recent studies indicate that plant mitochondria are unusually active in HGT, relative to all other organelles of multicellular eukaryotes [1]. The distinctive feature of plant mitochondria is the size of their genomes, which are much larger than those of other eukaryotes. Moreover, in addition to a large and complex main mitochondrial genome, plant mitochondria contain small circular and linear DNAs regarded as extrachromosomal replicons or plasmids [2]. The linear mitochondrial plasmids are present in many fungi and in some plant species, but they seem to be absent in most animal cells. They usually have in common an «invertron» structure that is characterized by the presence of terminal inverted repeats (TIRs) and proteins covalently attached to their 5 ' termini

(C) Institute of Molecular Biology and Genetics, NAS of Ukraine, 2014
[3]. The Brassica $11.6 \mathrm{~kb}$ plasmid, one of the linear mitochondrial plasmids in plants, shows a non-maternal inheritance, in contrast to mitochondrial genomes [4]. The origin of these plasmids is unknown, but indirect evidence indicates the possibility of horizontal transfer from fungal mitochondria. These pecularities suggest that plant mitochondria might possess a mechanism of natural competence to take up foreign DNA, resembling that of the process in the bacterial cells [5]. The aim of the project is to study different features of DNA import into plant mitochondria and into human mitochondria, for a better understanding of mitochondrial genetics and generation of biotechnological tools.

Materials and methods. We developed DNA uptake experiments with isolated plant mitochondria, using as substrates various sequences associated or not with the specific TIRs present at each end of the $11.6 \mathrm{~kb}$ linear plasmid from rapeseed (Brassica napus L.) [4]. 


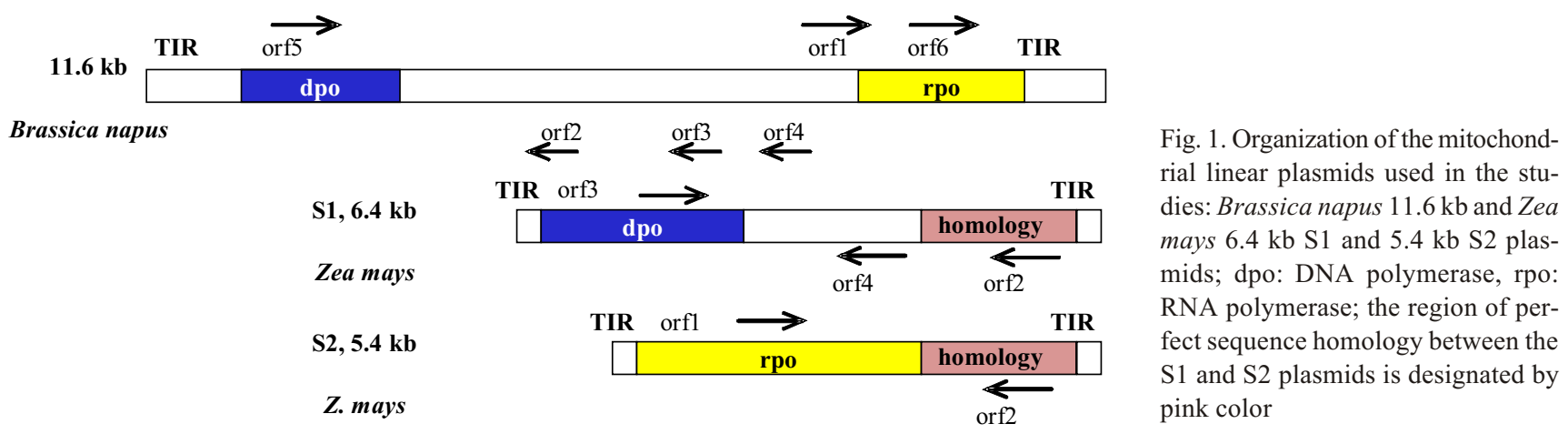

Further substrates for mitochondrial import were the $\mathrm{S} 1$ and S2 linear plasmids from maize (Zea mays) $[6,7]$. Organization of these plasmids is shown in Fig. 1. Isolation of mitochondria and uptake assays were performed as described earlier $[5,8]$.

Results and discussion. It has been shown previously [8] that (i) the efficiency of the import of large DNA molecules into plant mitochondria depends on the sequence and (ii) the specificity of DNA import can be mediated by the presence of certain elements in their sequence, especially TIRs at the ends of the molecules. Conversely, the efficiency of DNA import into mammalian mitochondria seemed to depend neither on the DNA sequence, nor on its size. Until now the role of the sequence and structure (in particular of the TIRs, which are different in linear plasmids from mitochondria of various plant species) in both mitochondrial DNA translocation and mitochondrial genetic processes (autonomous replication, integration into the genome, etc.) is unknown.

We addressed the possible universal role of the TIRs of mitochondrial linear plasmids from Z. mays and Brassica in the mechanism of DNA import into plant mitochondria. Using a vector containing the TIRs (327 bp) from the $11.6 \mathrm{~kb} \mathrm{~B}$. napus plasmid [4], we obtained several DNA constructs and tested the importance of the size and DNA structure in the efficiency of the import in-

A

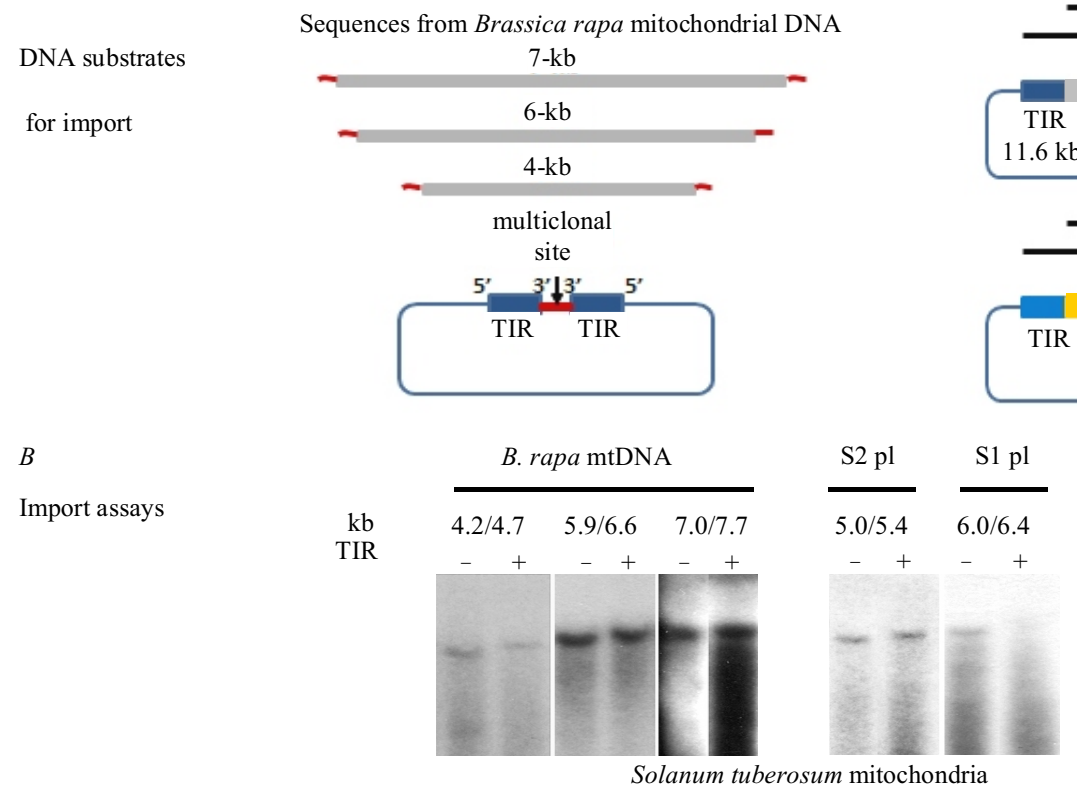

Fig. 2. Import of «medium» size DNA into Solanum tuberosum mitochondria does not depend on the presence of TIRs from mitochondrial linear plasmids: $A$-different sequences from the Brasica rapa mitochondrial genome were cloned between the TIRs from the $B$. napus $11.6 \mathrm{~kb}$ plasmid (the Zea mays S1 and S2 plasmids were cloned in parallel; all sequences were subsequently amplified by PCR with or without the TIRs); $B$ - the amplified PCR products were radioactively labeled and used as substrates for import into isolated S. tuberosum mitochondria. Nucleic acids subsequently recovered in the mitochondrial fraction were analyzed by agarose gel electrophoresis, Southern blotting and autoradiography 
to plant mitochondria (Fig. 2, $A$ ). The DNA sequences of Z. mays linear plasmids, S1 [6] and S2 [7] with or without TIRS (208 bp) were also cloned and used as substrates for import assays (Fig. 2, B). Using radioactively labeled DNA subst rates and the in organello potato $(S$. tuberosum) mitochondrial import system [5], it was established that the import efficiency has a non-linear dependence on DNA size: DNA fragments of 6-7 kb in size can be imported into $S$. tuberosum mitochondria more effectively than molecules with a $4 \mathrm{~kb}$ size. It was also shown (Fig. 2) that import into plant mitochondria of DNA molecules of «medium» sizes, $i$. e. between 4 and $7 \mathrm{~kb}$, barely has any sequence specificity: neither TIRs from the $11.6 \mathrm{~kb}$ Brassica plasmid, nor TIRs from the $Z$. mays S-plasmids influenced DNA import into $S$. tuberosum mitochondria. Conversely, the role of the TIRs from the $11.6 \mathrm{~kb}$ linear plasmid in the import of large DNA molecules was established earlier for the $B$. rapa mitochondria [8].

Conclusions. The data obtained support a speciesspecific import mechanism of the mitochondrial linear plasmids, and more generally of large DNA molecules, into plant mitochondria, which needs further investigation.

Funding. The work was supported by the Russian Fund for Basic Research (12-04-01400 and 12-04-01027) and the French Ministry for Research (Investis sements d'Avenir/Laboratoire d'Excellence MitoCross). The equipment of the Baikal Analytical Center (BAC) at the Presidium of ISC SB RAS was used for this work.

Специфіка імпорту ДНК в ізольованих мітохондріях з рослин і ссавців

М. В. Кулінченко, Н. Ібрахім, К. С. Кліменко,

Ю. М. Константинов, Ф. Вебер-Лотфі, А. Дитриш

\section{Резюме}

Мета. Вивчення відмінностей в імпорті ДНК у мітохондрії рослин і людини для кращого розуміння генетики мітохондрій та розробки біотехнологічних підходів до ї̈ дослідження. Методи. Експерименти з імпорту ДНК в ізольоовані мітохондрії рослин з використанням як субстратів послідовностей, які містять або не містять специфічних кінцевих інвертованих повторів (КІП), характерних для лінійних плазмід рослинних мітохондрій. Результати. Встановлено, що ефективність імпорту ДНК у мітохондрії нелінійно залежить від розміру ДНК. Показано, що імпорт у рослинні мітохондрії молекул ДНК «середніх» розімрів (4-7 тис. n. н.) має незначну структурну специфічність: ані КІП плазміди 11,6 тис. п. н. з Brassica napus, ані КIП S-плазмід із Zea mays не чинять впливу на імпорт ДНК у мітохондрії Solanum tuberosum. Висновки. Отримані дані свідчать на користь гіпотези існування ви- доспецифічного механізму перенесення мітохондріальних лінійних плазмід у рослинні мітохондрії.

Ключові слова: імпорт ДНК у мітохондрії, мітохондріальні лінійні плазміди рослин, мітохондріальний геном.

Специфика импорта ДНК в изолированных митохондриях растений и млекопитающих

М. В. Кулинченко, Н. Ибрагим, Е. С. Клименко, Ю. М. Константинов, Ф. Вебер-Лотфи, А. Дитриш

Резюме

Цель. Изучение различных свойств импорта ДНК в митохондрии растений и человека для лучшего понимания генетики митохондрий и разработки биотехнологических подходов для ее исследования. Методы. Эксперименты по импорту ДНК в изолированные митохондрии растений с использованием в качестве субстратов последовательностей, содержащих или не содержащих специфических концевых инвертированных повторов (КИП), характерных для линейных плазмид растительных митохондрий. Результаты. Установлено, что эффективность импорта ДНК в митохондрии имеет нелинейную зависимость от размера ДНК. Показано, что импорт в растительные митохондрии молекул ДНК «средних» размеров (4-7 тыс. п. н.) имеет незначительную структурную специфичность: ни КИП плазмиды 11,6 тыс. п. н. из Brassica nаpus, ни КИП S-плазмиды из Zea тауs не оказывают влияния на импорт ДНК в митохондрии Solanum tuberosum. Выводы. Полученные данные свидетельствуют в пользу гипотезы существования видоспецифического механизма переноса митохондриальных линейных плазмид в растительные митохондрии.

Ключевые слова: импорт ДНК в митохондрии, митохондриальные линейные плазмиды растений, митохондриальный геном.

\section{REFERENCES.}

1. Mower JP, Jain K, Hepburn NJ. The role of horizontal transfer in shaping the plant mitochondrial genome. Adv Bot Res. 2012; 63:41-69.

2. Handa $H$. Linear plasmids in plant mitochondria: peaceful coexistence or malicious invasions? Mitochondrion. 2008; 8 (1):15-25.

3. Sakaguchi K. Invertrons, a class of structurally and functionally related genetic elements that includes linear DNA plasmids, transposable elements, and genomes of adeno-type viruses. Microbiol Rev. 1990; 54(1):66-74.

4. Handa H, Itani K, Sato H. Structural features and expression analysis of a linear mitochondrial plasmid in rapeseed (Brassica napus L.). Mol Genet Genomics. 2002; 267(6):797-805.

5. Koulintchenko M, Konstantinov Y, Dietrich A. Plant mitochondria actively import DNA via the permeability transition pore complex. EMBO J. 2003; 22(6):1245-1254.

6. Paillard M, Sederoff RR, Levings CS. Nucleotide sequence of the S-1 mitochondrial DNA from the S cytoplasm of maize. EMBO J. 1985; 4(5):1125-8.

7. Levings CS, Sederoff RR. Nucleotide sequence of the S-2 mitochondrial DNA from the S cytoplasm of maize. Proc Natl Acad Sci USA. 1983; 80(13):4055-9.

8. Ibrahim N, Handa H, Cosset A, Koulintchenko M, Konstantinov $Y$, Lightowlers RN, Dietrich A, Weber-Lotfi F. DNA delivery to mitochondria: sequence specifity and energy enhancement. Pharm Res. 2011; 28(11):2871-82.

Recieved 01.09.13 